\title{
PERLAKUAN AKUNTANSI PERSEDIAAN BARANG DAGANGAN DAN PENGARUHNYA TERHADAP BEBAN POKOK PENJUALAN
}

\author{
Aloisius Hama \\ Sekolah Tinggi Ilmu Ekonomi(STIE) Yapan \\ Jalan IKIP Gunung Anyar Blok E No 152-154 dan 197-198, Surabaya
}

\begin{abstract}
Objectives to be achieved in this study is to know the accounting treatment of Merchandise Inventory which affects the Cost of Goods Sold on PT. Setia Makmur, Surabaya and can be used as input material of the company, to be able to use more accurate inventory method in determining Cost of Goods Sold in relation to Financial Statement. The accounting treatment for inventory is important for many companies, especially trading and manufacturing companies, as it has a significant effect on the presentation in the Balance Sheet and Income Statement. PT. Setia Makmur, Surabaya uses the Physical Method to record its inventory and LIFO Method (MTKP) to conduct an assessment of its Merchandise Inventory. The use of the Physical Method for the recording of Merchandise Inventory has a disadvantage from the point of internal control. The use of the LIFO Method (MTKP) in the Merchandise Inventory assessment is not in accordance with the Financial Accounting Standards which only allow the Special Identification Method, the FIFO Method (MPKP) and the Average Method. The mistake in choosing the right inventory valuation method will result in the presentation of Inventory, Cost of Goods Sold and Net Income which is overstated or understated.
\end{abstract}

\begin{abstract}
ABSTRAK
Tujuan yang ingin dicapai dalam penelitian ini adalah untuk mengetahui perlakuan akuntansi Persediaan Barang Dagangan yang berpengaruh terhadap Beban Pokok Penjualan pada PT. Setia Makmur, Surabaya serta dapat digunakan sebagai bahan masukan perusahaan, untuk dapat menggunakan metode persediaan yang lebih tepat dalam penentuan Beban Pokok Penjualan dalam kaitannya dengan Laporan Keuangan. Perlakuan akuntansi untuk persediaan menjadi penting bagi banyak perusahaan, khususnya perusahaan dagang dan manufaktur, karena mempunyai pengaruh signifikan terhadap penyajian di Neraca dan Laporan Perhitungan Laba Rugi. PT. Setia Makmur, Surabaya menggunakan Metode Fisik (Physical Method) untuk mencatat persediaannya dan Metode LIFO (MTKP) untuk melakukan penilaian terhadap Persediaan Barang Dagangannya. Penggunaan Metode Fisik (Physical Method) untuk pencatatan Persediaan Barang Dagangan mempunyai kelemahan dari sudut pengendalian internal. Sedangkan
\end{abstract}


penggunaan Metode LIFO (MTKP) dalam penilaian Persediaan Barang Dagangan tidak sesuai dengan Standar Akuntansi Keuangan yang hanya memperbolehkan Metode Identifikasi Khusus, Metode FIFO (MPKP) dan Metode Average (Ratarata). Kekeliruan dalam pemilihan metode penilaian persediaan yang tepat akan berakibat pada penyajian Persediaan, Beban Pokok Penjualan dan Laba Bersih yang disajikan terlalu tinggi (overstated) atau terlalu rendah (understated).

Keywords: merchandise inventory, physical method, perpetual method, LIFO, FIFO, average.

\section{PENDAHULUAN}

Dalam era globalisasi saat ini, tingkat persaingan antar perusahaan yang ada semakin ketat. Dengan adanya pasar bebas ASEAN (ASEAN Economic Community), perusahaan terlibat dalam persaingan yang semakin ketat dan luas, tidak hanya bersaing dengan produk-produk yang diproduksi di dalam negeri, tetapi juga produk luar negeri yang bebas masuk ke dalam negeri tanpa dikenai bea masuk dan regulasi yang ketat dari pemerintah. Untuk menyiasati kondisi tersebut perusahaan harus menciptakan kinerja yang efektif dan efisien terutama dalam masalah financial perusahaan.

Perusahaan merupakan kesatuan ekonomis yang didirikan untuk mencapai suatu tujuan umum, yaitu memperoleh laba. Di dalam kegiatannya untuk mencapai tujuan tersebut, setiap perusahaan baik itu manufaktur maupun perusahaan dagang akan melakukan kegiatan pembelian dan penjualan. Oleh karena itu perusahaan perlu melakukan penilaian terhadap semua persediaan yang dibeli dan dijual.

Persediaan adalah suatu aktiva yang meliputi semua barang yang dimiliki perusahaan pada saat tertentu dengan tujuan untuk dijual atau dikonsumsi dalam satu siklus operasi normal perusahaan. Jenis-jenis persediaan terdiri dari bahan baku, barang dalam proses, bahan penolong, barang jadi, dan persediaan lain-lain. Penilaian persediaan dilakukan dengan tujuan supaya dapat diketahui berapa nilai barang yang tersisa dan berapa nilai barang yang telah dijual. Dengan demikian akan bisa diketahui berapa jumlah laba yang diperoleh.

Metode pencatatan persediaan terdiri dari Metode Fisik (Physical Method) dan Metode Perpetual (Perpetual Method). Sedangkan metode penilaian persediaan terdiri dari Metode Identifikasi Khusus, Metode FIFO (MPKP), Metode LIFO (MTKP) dan Metode Rata-rata/Average (bergerak dan tertimbang). Dalam keadaan inflasi, penentuan persediaan mempunyai peranan yang sangat penting dalam penyusunan laporan keuangan pada perusahaan. Prinsip-prinsip akuntansi menetapkan bahwa persediaan harus dicatat dan dilaporkan sebesar harga perolehannya, hal ini berlaku baik untuk Metode Fisik maupun Perpetual. Metode penilaian persediaan yang paling umum digunakan ada dua, yaitu Metode FIFO dan Rata-rata/Average.

Penggunaan metode penilaian persediaan yang berbeda akan berpengaruh terhadap penentuan besarnya Beban Pokok Penjualan dan laba atau 


\section{Perlakuan Akuntansi Persediaan Barang Dagangan dan Pengaruhnya \\ Terhadap Be6an Pokok Penjualan}

rugi yang diperoleh oleh suatu perusahaan. Jadi perhitungan laba atau rugi suatu perusahaan dapat menghasilkan nilai yang berbeda, menjadi lebih besar atau lebih kecil, jika perusahaan menggunakan suatu metode penilaian persediaan tertentu. Oleh karena itu pemilihan metode penilaian persediaan yang tepat akan menentukan akurasi dalam perhitungan Beban Pokok Penjualan dan laba atau rugi.

Dalam penelitian ini akan diteliti mengenai pengaruh penggunaan metode penilaian persediaan terhadap perhitungan Beban Pokok Penjualan dan laba atau rugi yang diperoleh suatu perusahaan. Penelitian ini bersifat studi kasus dengan mengambil objek penelitian pada PT. Setia Makmur, Surabaya. Di sini akan dianalisis apakah metode penilaian persediaan yang digunakan sudah tepat atau tidak.

\section{TINJAUAN PUSTAKA}

\section{Pengertian dan Penggolongan Akuntansi}

Pengertian akuntansi menurut Baridwan (2002) adalah suatu kegiatan jasa yang fungsinya adalah menyediakan data kuantitatif, terutama yang mempunyai sifat keuangan dari kesatuan usaha ekonomi yang dapat digunakan dalam pengambilan. Keputusankeputusan ekonomi dalam memilih alternatif dari suatu keadaan. Sedangkan menurut Jusup (2005) akuntansi adalah proses pencatatan, penggolongan, peringkasan, pelaporan dan penganalisaan data keuangan suatu organisasi. Harahap (2015) mendefinisikan akuntansi adalah suatu seni untuk mencatat, mengklasifikasikan, melaporkan dalam bentuk laporan keuangan atas semua transaksi-transaksi yang telah dilaksanakan oleh suatu perusahaan.
Dengan demikian dapat disimpulkan bahwa akuntansi adalah proses pencatatan, penggolongan, peringkasan, pelaporan dan penganalisaan data keuangan dalam suatu organisasi yang dapat digunakan untuk pengambilan keputusan ekonomi dalam memilih alternatif dari suatu keadaan.

Akuntansi dapat dibedakan menjadi akuntansi yang ditujukan untuk organisasi yang bertujuan untuk mencari keuntungan dan organisasi yang tidak bertujuan untuk mencari keuntungan (nirlaba). Organisasi yang dimaksudkan untuk mencari keuntungan adalah perusahaan yang didirikan untuk kegiatan bisnis dengan orientasi mendapatkan keuntungan. Sedangkan organisasi nirlaba adalah organisasi yang didirikan tidak untuk mencari keuntungan dan dapat berupa yayasan, lembaga swadaya masyarakat, organisasi sosial dan kemasyarakatan dan bentuk organisasi nirlaba lainnya. Pemerintah termasuk organisasi nirlaba. Akuntansi yang digunakan untuk organisasi bisnis dikenal sebagai akuntansi bisnis dan akuntansi untuk organisasi nirlaba biasanya dikenal sebagai akuntansi sektor publik.

Secara umum akuntansi bisnis yang ditujukan untuk organisasi yang berorientasi untuk mencari keuntungan dapat digolongkan lagi menjadi 2, yaitu akuntansi keuangan dan akuntansi manajemen. Akuntansi keuangan dimaksudkan untuk menghasilkan suatu laporan keuangan yang diperlukan guna penyediaan informasi keuangan yang akan dipakai oleh semua pihak yang berkepentingan terhadap perusahaan (stakeholder) untuk pengambilan keputusan. Pihak yang berkepentingan terhadap laporan keuangan ini dapat dibedakan menjadi pihak internal perusahaan yang biasanya dikenal seba- 
gai pengguna internal dan pihak eksternal perusahaan yang biasa disebut sebagai pengguna eksternal. Pengguna internal adalah pihak manajemen dari level yang paling atas sampai dengan level paling bawah. Sedangkan pengguna eksternal adalah pihak-pihak di luar perusahaan yang terdiri dari: pemegang saham, kreditur, investor, instansi pajak dan pihak-pihak eksternal lainnya. Laporan keuangan yang dihasilkan oleh akuntansi keuangan akan dipakai pihak-pihak yang berkepentingan, baik pengguna internal maupun pengguna eksternal sebagai salah satu informasi yang dipertimbangkan untuk pengambilan keputusan.

Akuntansi manajemen dimaksudkan untuk menghasilkan informasi dan laporan yang khusus ditujukan untuk kepentingan manajemen. Informasi dan laporan yang dihasilkan akuntansi manajemen hanya khusus dipakai untuk kepentingan manajemen dalam pengambilan keputusan operasional.

\section{Laporan Keuangan}

Laporan keuangan sangat dibutuhkan oleh berbagai pihak yang berkepentingan terhadap perusahaan, karena laporan keuangan dapat digunakan sebagai bahan pertimbangan dalam setiap pengambilan keputusan ekonomi. Kepentingan terhadap perkembangan suatu perusahaan sangatlah perlu untuk mengetahui kondisi keuangan perusahaan. Suatu perusahaan akan dapat diketahui perkembangannya dari laporan keuangan perusahaan yang bersangkutan.

Laporan keuangan untuk organisasi bisnis akan terdiri dari: Neraca, Laporan Perhitungan Laba Rugi, Laporan Ekuitas, Laporan Arus Kas dan Catatan atas Laporan Keuangan.
Laporan keuangan ini akan disusun dengan pedoman Standar Akuntansi Keuangan (SAK) yang disusun oleh Ikatan Akuntansi Indonesia.

Laporan keuangan dibuat untuk mengambil keputusan ekonomi bagi pihak internal maupun eksternal perusahaan. Dalam kerangka dasar penyusunan laporan keuangan, Ikatan Akuntan Indonesia (2012) mengemukakan bahwa laporan keuangan disusun dengan tujuan sebagai berikut:

1) Menyediakan informasi yang menyangkut posisi keuangan, kinerja serta perubahan posisi keuangan suatu perusahaan yang bermanfaat bagi sejumlah besar pemakai dalam pengambilan keputusan.

2) Laporan keuangan disusun untuk memenuhi kebutuhan bersama sebagian besar pemakai. Namun demikian, laporan keuangan tidak menyediakan semua informasi yang mungkin dibutuhkan dalam pengambilan keputusan ekonomi, karena secara umum hanya menggambarkan pengaruh keuangan dari kejadian di masa lalu, dan tidak diwajibkan untuk menyediakan informasi non keuangan.

3) Laporan keuangan juga menunjukkan apa yang telah dilakukan manajemen (stewardship) atau pertanggungjawaban manajemen atas sumber daya yang dipercayakan kepadanya. Pemakai yang ingin menilai apa yang telah dilakukan atau pertanggungjawaban manajemen berbuat demikian agar mereka dapat membuat keputusan ekonomi. Keputusan ini mungkin mencakup keputusan untuk menahan atau menjual investasi mereka dalam perusahaan atau antara keputusan untuk menahan atau mengganti manajemen. 


\section{Perlakuan Akuntansi Persediaan Barang Dagangan dan Pengarufnya \\ Terhadap Be6an Pokok Penjualan}

\section{Pendapatan}

Dalam perusahaan dagang dan industri, pendapatan diperoleh dari hasil kegiatan penjualan. Unsur-unsur dalam penjualan terdiri dari:

a) Penjualan Kotor.

b) Retur Penjualan.

c) Potongan Penjualan.

d) Penjualan Bersih.

Penjualan Bersih dapat dihitung dari Penjualan Kotor setelah dikurangi dengan Retur Penjualan dan Potongan Penjualan. Contoh: diketahui Penjualan Kotor sebesar Rp. 25.000.000,-, Retur Penjualan sebesar Rp. 125.000,dan Potongan penjualan sebesar Rp. 150.000,-, maka Penjualan Bersih dapat dihitung sebagai berikut:

Penjualan bersih $=$ Rp. 25.000.000,- Rp. 125.000,- - Rp. 150.000,- = Rp. 24.725.000,-.

\section{Beban Pokok Penjualan}

Beban Pokok Penjualan adalah seluruh biaya yang dikeluarkan untuk memperoleh barang yang dijual atau harga perolehan dari harga barang yang dijual. Menurut Harahap (2005) ada dua manfaat dari Beban Pokok Penjualan:

1. Sebagai patokan untuk menentukan harga jual.

2. Untuk mengetahui laba yang diinginkan perusahaan. Apabila harga jual lebih besar dari Beban Pokok Penjualan, maka akan diperoleh laba, dan sebaliknya apabila harga jual lebih rendah dari Beban Pokok Penjualan akan diperoleh kerugian.

Apabila perusahaan menggunakan metode pencatatan persediaan dengan Metode Fisik, maka untuk menghitung Beban Pokok Penjualan harus diperhatikan terlebih dahulu unsur-unsur yang berhubungan dengan Beban
Pokok Penjualan. Unsur-unsur itu antara lain:

a. Persediaan Awal dan Akhir.

b. Pembelian.

c. Biaya Angkut Pembelian.

d. Retur Pembelian dan Pengurangan Harga.

e. Potongan Pembelian.

Beban Pokok Penjualan dapat dihitung dengan cara menambahkan Persediaan Awal dengan Pembelian Bersih dan mengurangkannya dengan Persediaan Akhir. Pembelian Bersih dihitung dengan menambahkan Pembelian dengan Biaya Angkut Pembelian dan mengurangkannya dengan Retur Pembelian dan Pengurangan Harga serta Potongan Pembelian.

\section{Pengertian dan Fungsi Persediaan}

Salah satu pos penting yang disajikan dalam laporan keuangan adalah persediaan. Istilah persediaan mencakup barang yang ditujukan untuk dijual dalam pelaksanaan normal suatu badan usaha, serta bahan baku dan perlengkapan yang akan digunakan dalam penjualan maupun proses produksi. Yang tidak termasuk dalam kategori persediaan adalah perlengkapan yang akan dikonsumsi dalam operasional non produksi, sekuritas yang dimiliki untuk dijual kembali, tetapi bersifat insidentil terhadap operasi perusahaan, serta pabrik dan peralatan yang digunakan atau sedang menunggu pelepasan final setelah digunakan.

Persediaan menurut Horngren et al. (2004) adalah persediaan yang merupakan barang dan menjadi suatu elemen yang penting bagi perusahaan. Menurut Kieso dan Weygandt (2000) persediaan adalah pos harta yang ditahan untuk dijual dalam kegiatan usaha yang biasa atau barang yang akan digunakan atau dikonsumsi da- 
lam memproduksi barang yang akan dijual.

Samryn (2015) menyatakan pengertian persediaan dibedakan menjadi dua yaitu:

1. Pada perusahaan dagang, pengertian persediaan adalah barang yang tersedia untuk dijual kembali.

2. Pada perusahaan manufaktur, pengertian persediaan dapat berupa bahan mentah, barang dalam proses produksi dan barang jadi yang siap untuk dijual kembali.

Persediaan (inventory) dapat memiliki berbagai fungsi penting yang menambah fleksibilitas dari operasi suatu perusahaan. Menurut Smith dan Skousen (2001) penggunaan persediaan yaitu:

1. Untuk memberikan suatu stock barang-barang agar dapat memenuhi atau mengantisipasi permintaan yang akan timbul dari pembeli atau konsumen.

2. Untuk memasangkan produksi dengan distribusi misalnya: bila permintaan tinggi hanya pada musim dingin, sehingga biaya kekurangan stock dan kehabisan stock dapat dihindari. Demikian pula bila pasokan berfluktuasi, persediaan bahan baku ekstra mungkin diperlukan termasuk mengantisipasi pada proses produksinya.

3. Untuk mengambil keuntungan dari potongan jumlah pembelian, karena pembelian dalam jumlah besar secara substansial menurunkan biaya produk.

4. Untuk melakukan hedging terhadap inflasi dalam perubahan harga.

5. Untuk menghindari dari kekurangan stock yang dapat terjadi karena cuaca, barang di tangan ekstra dapat mengurangi resiko kehabisan stock.

\section{Pencatatan Persediaan}

Untuk mencatat persediaan barang ada 2 metode yang dapat digunakan, yaitu:

1. Metode Fisik (Physical Method)

Pada metode ini, setiap transaksi pembelian barang akan dicatat nilai pembeliannya dalam akun Pembelian, tetapi kuantitas barang yang dibeli tidak pernah dicatat. Sedangkan pada transaksi penjualan barang hanya dicatat nilai penjualan pada akun Penjualan, tetapi tidak penah dicatat kuantitas barang yang dijual serta tidak pernah dicatat berapa nilai Beban Pokok Penjualan atas barang yang dijual tersebut. Dengan metode ini, maka setiap saat kuantitas dan nilai persediaan barang tidak dapat diketahui. Untuk mengetahui kuantitas dan nilai persediaan barang pada suatu saat tertentu harus dilakukan perhitungan fisik barang yang masih ada terlebih dahulu, karena tidak ada catatan yang bisa menginformasikan jumlah dan nilai persediaan pada suatu saat tertentu. Perhitungan fisik barang biasanya baru dilakukan pada akhir periode untuk menentukan jumlah dan nilai persediaan barang guna menghitung besarnya nilai Beban Pokok Penjualan dan laba rugi. Metode ini tidak dapat memberikan suatu pengendalian internal yang memadai untuk pengendalian dan pengawasan persediaan barang. Namun untuk alasan kepraktisan, metode ini sering digunakan untuk persediaan barang yang jumlahnya banyak, sulit untuk dihitung kuantitasnya setiap saat dan harga per unit barang cenderung kecil. Penggunaan metode ini biasanya diikuti dengan prosedur pengawas- 


\section{Perlakuan Akuntansi Persediaan Barang Dagangan dan Pengaruhnya \\ Terhadap Be6an Pokok Penjualan}

an tambahan yang lebih ketat dan baik terhadap persediaan barang.

2. Metode Perpetual (Perpetual Method)

Pada metode ini semua transaksi pembelian dan penjualan serta keluar dan masuknya barang akan dicatat, baik kuantitasnya maupun nilainya. Untuk pencatatan nilai persediaan barang total akan dilakukan pada akun Pembelian dan Penjualan. Sedangkan kuantitas, harga satuan dan nilai total barang yang masuk dan keluar akan dicatat di dalam Kartu Persediaan. Pada saat terjadi transaksi penjualan, maka selain dilakukan pencatatan nilai barang yang dijual ke dalam akun Penjualan, juga dilakukan pencatatan nilai Beban Pokok Penjualan ke dalam akun Beban Pokok Penjualan. Dengan metode ini, maka kuantitas dan nilai persediaan barang akan dapat diketahui setiap saat. Hal ini menyebabkan kontrol terhadap kuantitas dan nilai persediaan barang akan dapat dilakukan dengan lebih baik. Jika terjadi kehilangan barang akan dapat diketahui segera.

\section{Penilaian Harga Pokok Persediaan}

Menurut Smith dan Skousen (2001) harga pokok persediaan sangat penting dan harga pokok persediaan barang dagangan ditentukan oleh gabungan dua faktor, yaitu kuantitas dan harga pokok persediaan per unit. Kuantitas persediaan dapat diperoleh melalui perhitungan fisik. Harga pokok persediaan per unit adalah harga untuk memperoleh persediaan per unit. Di samping harga beli, yang termasuk dalam harga pokok persediaan per unit adalah semua biaya yang terjadi sampai dengan barang siap dijual, misalnya: biaya pengangkutan, bea masuk dan asuransi. Untuk menghitung harga pokok persediaan per unit ada beberapa metode yang dapat digunakan, yaitu Metode Identifikasi Khusus, Metode FIFO (First In First Out) atau MPKP dan Metode Rata-rata/Average. Di samping itu ada 1 metode lagi yang bisa digunakan yaitu metode LIFO (Last In First Out) atau MTKP. Namun Ikatan Akuntan Indonesia (2012: 14.4) menyatakan hanya ada Metode Identifikasi Khusus, Metode MPKP (Masuk Pertama Keluar Pertama) yaitu FIFO dan Metode Rata-rata Tertimbang yaitu Average yang bisa digunakan untuk menghitung harga pokok persediaan dan tidak memperkenankan penggunaan Metode MTKP (Masuk Terakhir Keluar Pertama) yaitu LIFO.

\section{Metode Identifikasi Khusus}

Menurut Smith dan Skousen (2001) Metode Identifikasi Khusus adalah metode yang biayanya dialokasikan ke barang-barang yang masih ada pada perusahaan pada akhir periode sesuai dengan biaya aktual dari unit barang secara khusus. Penggunaan metode ini memerlukan pengidentifikasian biaya historis dan fisik dari masing-masing unit persediaan sampai saat penjualannya.

Untuk itu setiap unit barang akan diberikan suatu identitas khusus yang unik, sehingga memudahkan untuk diidentifikasi pada waktu unit barang tersebut dijual. Dengan Metode Identifikasi Khusus arus biaya yang tercatat ditandingkan dengan arus fisik barang. Metode ini biasanya digunakan pada persediaan barang dengan jumlah unit yang tidak terlalu banyak kuantitasnya, tetapi dengan harga per unit yang relatif tinggi. 


\section{Metode FIFO (First In First Out)}

Metode FIFO (First In First Out) atau MPKP (Masuk Pertama Keluar Pertama) merupakan suatu metode penilaian persediaan yang beranggapan bahwa barang yang masuk (dibeli) lebih dahulu dianggap dikeluarkan lebih dahulu (Baridwan, 2002).

Menurut Smith dan Skousen (2001) Metode FIFO didasarkan pada asumsi bahwa biaya harus dibebankan ke pendapatan sesuai dengan urutan terjadinya. Dengan demikian persediaan yang dipakai/dijual akan dihitung berdasarkan harga pembelian terbaru. Penggunaan Metode FIFO untuk perhitungan harga pokok persediaan dapat dilihat pada contoh berikut ini. Misalkan suatu perusahaan mempunyai Persediaan Barang Dagangan Awal per-tanggal 1 Januari sebanyak 200 unit dengan harga per-satuan sebesar Rp. 10,-, sehingga total nilai Persediaan Barang Dagangan Awal adalah 200 unit $x$ Rp. 10,- = Rp. 2.000,-. Kemudian data pembelian yang dilakukan perusahaan pada bulan Januari seperti terlihat pada Tabel 1 .

Tabel 1

Data Pembelian Barang Dagangan Periode Bulan Januari

\begin{tabular}{|l|c|c|c|}
\hline \multirow{2}{*}{ Tanggal } & \multicolumn{3}{|c|}{ Pembelian } \\
\cline { 2 - 4 } & $\begin{array}{c}\text { Kuantitas } \\
\text { (unit) }\end{array}$ & $\begin{array}{c}\text { Harga } \\
\text { Satuan } \\
\text { (Rp.) }\end{array}$ & $\begin{array}{c}\text { Jumlah } \\
\text { Harga } \\
\text { (Rp.) }\end{array}$ \\
\hline 12 Jan & 400 unit & 13 & 5.200 \\
\hline 26 Jan & 300 unit & 12 & 3.600 \\
\hline 30 Jan & 100 unit & 11 & 1.100 \\
\hline & 800 unit & & 9.900 \\
\hline
\end{tabular}

Perhitungan fisik pada tanggal 31 Januari menunjukkan jumlah Persediaan Barang Dagangan sejumlah 300 unit yang ada dalam gudang. Harga satuan pembelian yang terbaru dapat digunakan untuk menetapkan nilai unit-unit tersebut:
Pembelian terakhir 30 Januari $=100$ unit + pembelian 26 Januari $=200$ unit.

Jadi nilai saldo Persediaan Akhir Barang Dagangan per-31 Januari, dengan Metode FIFO adalah:

100 unit @ Rp. 11,-=Rp.1.100,200 unit @ Rp. 12,- = $\underline{\text { Rp. 2.400,- + }}$ 300 unit $\quad=$ Rp. 3.500,-

Jika Persediaan Akhir dicatat dengan nilai Rp. 3.500, maka Beban Pokok Penjualan adalah $=$ Rp. $2.000,-+$ Rp. 9.900,- - Rp. 3.500,- = Rp. 8.400,-Jadi pendapatan akan dibebani dengan Beban Pokok Penjualan yang dihitung dari biaya persediaan yang diperoleh paling dini. Metode FIFO dianggap sebagai metode yang paling logis dan realistis mengenai arus biaya apabila Metode Identifikasi Khusus dianggap tidak praktis, sulit atau tidak mungkin untuk dapat dilaksanakan.

\section{Metode Biaya Rata-rata (Average)}

Menurut Smith dan Skousen (2001) Metode Average merupakan suatu metode penilaian persediaan yang didasarkan pada rata-rata dari harga perolehan persediaan. Metode ini dianggap paling mudah dilaksanakan oleh perusahaan. Penggunaan Metode Average memberi peluang setiap harga beli mempengaruhi penilaian persediaan dan Beban Pokok Penjualan. Asumsi yang dipergunakan di sini adalah bahwa operasi pembelian dan penjualan mengakibatkan pengumpulan biaya dan pembebanan biaya ini pada barang-barang yang dijual dan barang-barang yang belum dijual dengan basis harga tunggal (single price). Harga tunggal ini diasumsikan sebagai harga unit yang mewakili semua barang-barang yang ditangani selama periode tertentu. 


\section{Perlakuan Akuntansi Persediaan Barang Dagangan dan Pengaruhnya Terhadap Be6an Pokok Penjualan}

Menurut Baridwan (2002) harga pokok persediaan dengan Metode Average mengasumsikan barang-barang yang akan dipakai untuk memproduksi atau dijual akan dibebani harga pokok rata-rata. Perhitungan harga pokok rata-rata dilakukan dengan cara membagi jumlah harga perolehan dengan kuantitasnya.

Menurut Smith dan Skousen (2001) Metode Average mengasumsikan bahwa barang-barang yang dijual harus dibebani dengan biaya rata-rata, di mana biaya rata-rata itu dipengaruhi atau dipertimbangkan menurut jumlah unit yang diperoleh pada masingmasing harga.

Persediaan dinyatakan dengan biaya rata-rata tertimbang per-unit. Dengan menggunakan data yang sama seperti sebelumnya maka biaya ratarata tertimbang $=($ Rp. $2.000,-+R p$. 9.900,-) : 1.000 unit $=\operatorname{Rp~11,9/unit.~}$ Nilai Persediaan Akhir=300 unit @ Rp. 11,9 = Rp. 3.570,-. Besar Beban Pokok Penjualan adalah $=($ Rp. 2.000,+ Rp. 9.900,- - Rp. 3.570,-) = Rp. $8.330,-$.

\section{Metode LIFO (Last In First Out)}

Metode LIFO (Last In First Out) atau Metode MTKP (Masuk Terakhir Keluar Pertama) merupakan suatu metode penilaian persediaan yang mempunyai anggapan bahwa barang yang keluar seharusnya dinilai dengan harga satuan masuk (dibeli) terakhir lebih dahulu, karena harga satuan masuk yang terakhir lebih relevan.

Berdasarkan data dari contoh yang sama sebelumnya, maka dengan Metode LIFO dapat ditentukan harga satuan yang dapat digunakan untuk menetapkan nilai unit persediaan yang masih ada pada akhir Januari sebesar 300 unit sebagai berikut:
Persediaan Awal 1 Januari $=200$ unit + pembelian 12 Januari $=100$ unit. Jadi nilai saldo Persediaan Akhir Barang Dagangan per 31 Januari, dengan metode LIFO adalah:

200 unit @ Rp.10,-=Rp.2.000,100 unit @ Rp. 13,-= Rp. 1.300,- + 300 unit $=$ Rp. 3.300,-

Jika Persediaan Akhir dicatat dengan nilai Rp. 3.300, maka Beban Pokok Penjualan $=$ Rp. 2.000,- + Rp. 9.900,- - Rp. 3.300,- = Rp. 8.600,-. Jadi pendapatan akan dibebani dengan Beban Pokok Penjualan yang dihitung dari biaya persediaan yang diperoleh paling akhir.

\section{Perbandingan Metode Penilaian Persediaan}

Walaupun secara teoritis entitas dapat menggunakan metode penilaian persediaan dengan Metode Identifikasi Khusus, FIFO (MPKP), Average (Rata-rata) dan LIFO (MTKP). Namun untuk penyusunan laporan keuangan di Indonesia yang berpedoman pada Standar Akuntansi Keuangan hanya memperbolehkan penggunaan Metode Identifikasi Khusus, FIFO (MPKP) dan Average (Rata-rata) (Ikatan Akuntan Indonesia, 2012: 14.4).

Penggunaan salah satu metode penilaian persediaan akan mempunyai dampak pada besarnya laba rugi yang diperoleh. Dalam kondisi ekonomi mengalami inflasi, maka penggunaan $\mathrm{Me}$ tode FIFO (MPKP) akan menghasilkan laba yang paling besar dan penggunaan Metode LIFO (MTKP) akan menghasilkan laba yang paling kecil serta penggunaan Metode Average (Rata-rata) akan menghasilkan laba di tengah-tengah antara laba yang diperoleh dengan Metode FIFO (MPKP) dan Metode LIFO (MTKP). 
Sedangkan dalam kondisi ekonomi sedang deflasi, maka penggunaan Metode FIFO (MPKP) akan menghasilkan laba yang paling kecil dan penggunaan Metode LIFO (MTKP) akan menghasilkan laba yang paling besar serta penggunaan Metode Average (Rata-rata) akan menghasilkan laba di tengah-tengah antara laba yang diperoleh dengan Metode LIFO (MTKP) dan Metode FIFO (MPKP).

Apabila Metode Identifikasi Khusus sulit atau tidak mungkin untuk digunakan, maka dari ketiga metode yang lain, yaitu FIFO, Average dan LIFO yang paling netral adalah penggunaan Metode Average, apalagi bila harga barang cenderung tidak stabil.

\section{METODE PENELITIAN \\ Teknik Pengumpulan Data}

Data yang digunakan dalam penelitian ini diperoleh dengan menggunakan teknik pengumpulan data sebagai berikut:

1. Dokumentasi yaitu cara untuk memperoleh data dan informasi dengan cara melihat, mempelajari, mengutip catatan dan dokumendokumen tertulis yang berkaitan dengan objek yang diteliti.

2. Studi Pustaka yaitu cara memperoleh data dengan membaca bukubuku perpustakaan untuk mendapatkan teori-teori yang dapat dijadikan landasan dalam pembahasan.

\section{Populasi dan Sampel}

Populasi dalam penelitian ini adalah seluruh data laporan keuangan, data persediaan dan data Beban Pokok Penjualan pada PT. Setia Makmur, Surabaya. Sedangkan sampel yang digunakan dalam penelitian ini adalah data laporan keuangan, data persediaan dan data perhitungan Beban Pokok
Penjualan pada PT. Setia Makmur, Surabaya untuk periode 1 tahun yang berakhir pada 31 Desember 2016.

\section{Jenis dan Sumber Data}

Data yang digunakan dalam penelitian ini masuk dalam jenis data kuantitatif yaitu data yang berupa angka-angka yang terdiri dari catatancatatan Persediaan Barang Dagangan dan laporan keuangan.

Data kuantitatif yang digunakan dalam penelitian ini berupa data sekunder, di mana data yang diperoleh bersumber dari PT. Setia Makmur, Surabaya. Data disusun sesuai dengan dokumen perusahaan dan dibantu dari berbagai buku dan literatur-literatur yang dapat dijadikan sebagai bahan acuan dalam penelitian.

\section{Teknik Analisis Data}

Setelah diperoleh data akan diolah dan dianalisis dengan cara:

a. Deskriptif, yaitu melukiskan atau menggambarkan keadaan objek yang diteliti dan menyajikan data yang diperoleh untuk dianalisis.

b. Analisis yaitu suatu upaya untuk menyempitkan dan membatasi penemuan-penemuan hingga menjadi suatu data yang teratur, serta tersusun dan lebih berarti. Proses ini sebagai usaha penemuan jawaban atas pertanyaan perihal hal-hal yang diperoleh dalam penelitian.

\section{Data yang Dikumpulkan}

Dalam mencatat persediaannya PT. Setia Makmur, Surabaya menggunakan Metode Fisik (Physical Method) dan untuk penilaian persediaan menggunakan Metode MTKP (Masuk Terakhir Keluar Pertama) atau LIFO. Data yang dikumpulkan dan diolah adalah data-data yang berkaitan de- 
ngan Laporan Perhitungan Laba Rugi, perhitungan Beban Pokok Penjualan, Neraca dan Rincian Penjualan untuk Tahun 2016 seperti nampak pada Tabel 1, Tabel 2, Tabel 3 dan Tabel 4.

Tabel 1

PT. Setia Makmur, Surabaya Laporan Perhitungan Laba Rugi Untuk Tahun yang Berakhir pada 31 Desember 2016

(Penilaian Persediaan Metode LIFO)

\begin{tabular}{|c|c|}
\hline Keterangan & $\begin{array}{c}\text { Jumlah } \\
\text { (Rp.) }\end{array}$ \\
\hline Penjualan & \\
\hline Penjualan tunai & 6.430 .807 .860 \\
\hline Penjualan kredit & 10.568 .824 .200 \\
\hline Total Penjualan & 16.999 .632 .060 \\
\hline Potongan Penjualan & $(865.806 .000)$ \\
\hline Return Penjualan & $(248.160 .180)$ \\
\hline Total Pot. Dan Retur Penjualan & $(1.113 .966 .180)$ \\
\hline Penjualan Bersih & 15.885 .665 .880 \\
\hline Beban Pokok Penjualan & $(11.801 .701 .826)$ \\
\hline Laba Kotor Usaha & 4.083 .964 .054 \\
\hline Beban Usaha : & \\
\hline Depart. Marketing & $(2.026 .116 .900)$ \\
\hline Depart. Finance dan & $(126.839 .040)$ \\
\hline Accounting & \\
\hline Depart. Direksi & $(64.408 .116)$ \\
\hline Depart. Manajer & $(7.788 .600)$ \\
\hline Total Beban Usaha & $(2.225 .152 .656)$ \\
\hline Laba Bersih Usaha & 1.858 .811 .398 \\
\hline $\begin{array}{l}\text { Pendapatan dan Beban Lain- } \\
\text { lain: }\end{array}$ & \\
\hline Pendapatan lain-lain & 69.594 .096 \\
\hline Beban lain-lain & $(49.839 .120)$ \\
\hline Laba Bersih & 1.878 .566 .374 \\
\hline $\begin{array}{l}\text { Rasio Laba Bersih dari } \\
\text { Penjualan Bersih }\end{array}$ & $11,83 \%$ \\
\hline
\end{tabular}

Sumber: PT. Setia Makmur, Surabaya

Tabel 2

PT. Setia Makmur, Surabaya

Perhitungan Beban Pokok Penjualan

Untuk Tahun yang Berakhir pada

31 Desember 2016

(Penilaian Persediaan Metode LIFO)

\begin{tabular}{|l|r|}
\hline Persediaan Awal & 11.097 .452 .330 \\
\hline Pembelian & 11.891 .911 .212 \\
\hline Barang tersedia untuk & 22.989 .363 .542 \\
\hline Persediaan Akhir & $(11.187 .661 .716)$ \\
\hline Beban Pokok Penjualan & 11.801 .701 .826 \\
\hline
\end{tabular}

Sumber: PT. Setia Makmur, Surabaya
Tabel 3

PT. Setia Makmur, Surabaya

Neraca

Per 31 Desember 2016

(Penilaian Persediaan Metode LIFO)

\begin{tabular}{l|r|}
\hline AKTIVA & \\
Aktiva Lancar: & \\
Kas dan setara kas & 843.122 .765 \\
Piutang Usaha & 2.667 .235 .650 \\
Putang lain-lain & 4.142 .955 .084 \\
Persediaan & 11.187 .661 .716 \\
Uang Muka Pembelian & 50.245 .865 \\
Biaya dibayar dimuka & 40.415 .498 \\
\hline Jumlah aktiva lancer & 18.931 .636 .578 \\
\cline { 2 - 2 } Aktiva Tetap : & \\
Nilai Perolehan & \\
Akumulasi Penyusutan & 2.980 .771 .258 \\
Jumlah aktiva tetap & $(1.455 .688 .839)$ \\
\cline { 2 - 2 } Total aktiva & 1.525 .082 .419 \\
\cline { 2 - 2 } KEWAJIBAN & \\
\cline { 2 - 2 } Kewajiban Jangka Pendek : & 20.456 .718 .997 \\
\cline { 2 - 2 } Hutang Giro & \\
Hutang Usaha & \\
Uang Muka Penjualan & 152.566 .927 \\
Hutang lain-lain & 5.922 .117 .967 \\
Jumlah kewajiban jangka pendek & 27.902 .393 \\
& 647.966 .533 \\
\cline { 2 - 2 } EKUITAS & 6.750 .553 .820 \\
\cline { 2 - 2 } Modal & \\
Laba ditahan & \\
Laba tahun berjalan & 10.439 .419 .764 \\
Jumlah ekuitas & 1.388 .179 .039 \\
Total kewajiban dan ekuitas & 1.878 .566 .374 \\
\cline { 2 - 2 } Sumber: PT Seta Makmur & 13.706 .165 .177 \\
\cline { 2 - 2 } & 20.456 .718 .997 \\
\hline
\end{tabular}

Sumber: PT. Setia Makmur, Surabaya

Tabel 4

PT. Setia Makmur, Surabaya Rincian Penjualan Tahun 2016

\begin{tabular}{|c|l|r|r|}
\hline No. & \multicolumn{1}{|c|}{ Nama Barang } & \multicolumn{1}{c|}{$\begin{array}{c}\text { Penjualan } \\
\text { Bruto }\end{array}$} & \multicolumn{1}{c|}{$\begin{array}{c}\text { Penjualan } \\
\text { Bersih }\end{array}$} \\
\hline 1 & Adalat Oros & 216.180 .348 & 183.503 .964 \\
\hline 2 & Cardio Aspirin & 30.079 .608 & 10.804 .752 \\
\hline 3 & Bayeuten Cream & 4.684 .417 .500 & 4.609 .115 .508 \\
\hline 4 & Cyproxin XR & 580.282 .188 & 577.629 .684 \\
\hline 5 & Glucobay & 6.038 .704 .212 & 5.494 .139 .028 \\
\hline 6 & Vapex Inbalant & 4.373 .584 .764 & 4.067 .546 .472 \\
\hline 7 & Mucopect & 276.181 .044 & 228.791 .088 \\
\hline 8 & Cedocard & 126.817 .716 & 103.011 .456 \\
\hline 9 & Primperan Drops & 243.107 .688 & 242.235 .408 \\
\hline 10 & Kamilloson Oint & 304.388 .376 & 250.055 .244 \\
\hline 11 & Hepa Balance & 120.304 .368 & 113.249 .028 \\
\hline 12 & $\begin{array}{l}\text { Flagystatin } \\
\text { Suppositoris }\end{array}$ & 5.584 .248 & 5.584 .248 \\
\hline Jumlah & 16.999 .632 .060 & 15.885 .665 .880 \\
\hline
\end{tabular}

Sumber: PT. Setia Makmur, Surabaya 
Dari data di atas nampak bahwa rasio laba bersih dari penjualan bersih sebesar $=$ Rp. 1.878.566.374,- : Rp. 15.885.665.880,- x $100 \%=11,83 \%$. Angka rasio ini lebih rendah dari angka rasio rata-rata 3 tahun terakhir (2013-2015) yang menunjukkan angka sebesar $15,1 \%$.

Pada waktu dilakukan evaluasi kerja akhir tahun, manajemen berkesimpulan kinerja operasional perusahaan tahun 2016 meningkat dibandingkan tahun-tahun sebelumnya dan seharusnya rasio laba bersih dari penjualan bersih juga meningkat. Namun fakta yang ada rasio laba bersih dari penjualan bersih justru menurun dari pada tahun-tahun sebelumnya.

Data pembelian barang dagangan yang didapat menunjukkan harga satuan barang yang dibeli cenderung naik terus dengan nilai yang cukup besar dibandingkan harga satuan barang dari pembelian sebelumnya dan harga satuan barang Persediaan Awal Barang Dagangan.

\section{ANALISIS DAN PEMBAHASAN}

Dalam menghitung harga pokok persediaan dan Beban Pokok Penjualan, PT. Setia Makmur, Surabaya menggunakan Metode LIFO (MTKP). Dalam kondisi harga pembelian yang cenderung naik, maka penggunaan Metode LIFO akan menghasilkan laba yang cenderung terlalu kecil (understated) dan Persediaan Barang juga dinilai terlalu rendah (understated). Hal ini mungkin bisa merupakan salah satu penyebab turunnya rasio laba bersih dari penjualan bersih PT. Setia Makmur, Surabaya di samping kemungkinan adanya penurunan kinerja operasional riil perusahaan.

Penggunaan metode penilaian persediaan dengan Metode LIFO
(MTKP) tidak sesuai dengan Standar Akuntansi Keuangan. Dalam Standar Akuntansi Keuangan metode penilaian persediaan yang diperbolehkan untuk digunakan adalah Metode Identifikasi Khusus, Metode FIFO (MPKP) dan Metode Average (Rata-rata) (Ikatan Akuntan Indonesia, 2012: 14.4). Pada Standar Akuntansi Keuangan sebelumnya memang Metode LIFO (MTKP) sempat diperbolehkan, tetapi kemudian oleh Ikatan Akuntan Indonesia Metode LIFO (MTKP) sudah tidak diperbolehkan digunakan untuk menilai Persediaan Barang dan menghitung Beban Pokok Penjualan.

Karena itu penggunaan Metode LIFO oleh PT. Setia Makmur, Surabaya sudah menyalahi pedoman yang diberikan dalam Standar Akuntansi Keuangan, sehingga laporan keuangan perusahaan dapat dianggap tidak menyajikan secara wajar kondisi keuangan dan hasil operasi perusahaan untuk tahun 2016, khususnya untuk penyajian pos Persediaan Barang di Neraca dan laba rugi di dalam Laporan Perhitungan Laba Rugi.

Pada PT. Setia Makmur, Surabaya tidak dimungkinkan menggunakan Metode Identifikasi Khusus, karena jumlah kuantitas Persediaan Barang Dagangan sangat banyak. Dalam kondisi harga satuan barang dagangan yang cenderung tidak stabil, maka penggunaan Metode Average (Ratarata) dinilai lebih tepat dan akan mampu menyajikan kondisi keuangan perusahaan yang lebih wajar pada laporan keuangan dibandingkan dengan metode penilaian persediaan lainnya.

Berdasarkan data yang diperoleh dari perusahaan setelah diolah, jika perusahaan menggunakan Metode Average untuk penilaian persediaan, dan menghitung Beban Pokok Penjual- 
an, maka Laporan Perhitungan Laba Rugi, perhitungan Beban Pokok Penjualan dan Neraca untuk Tahun 2016 seperti terlihat pada Tabel 5, Tabel 6 dan Tabel 7.

Tabel 5

PT. Setia Makmur, Surabaya

Laporan Perhitungan Laba Rugi

Untuk Tahun yang Berakhir pada 31 Desember 2016

(Penilaian Persediaan Metode Average)

\begin{tabular}{|c|c|}
\hline Keterangan & $\begin{array}{l}\text { Jumlah } \\
\text { (Rp.) }\end{array}$ \\
\hline \multicolumn{2}{|l|}{ Penjualan } \\
\hline Penjualan tunai & 6.430 .807 .860 \\
\hline Penjualan kredit & 10.568 .824 .200 \\
\hline Total Penjualan & 16.999 .632 .060 \\
\hline Potongan Penjualan & $(865.806 .000)$ \\
\hline Return Penjualan & $(248.160 .180)$ \\
\hline Total Pot. Dan Retur Penjualan & $(1.113 .966 .180)$ \\
\hline Penjualan Bersih & 15.885 .665 .880 \\
\hline Beban Pokok Penjualan & $(11.021 .354 .319)$ \\
\hline Laba Kotor Usaha & 4.864 .311 .561 \\
\hline \multicolumn{2}{|l|}{ Beban Usaha: } \\
\hline$\overline{\text { Depart. Marketing }}$ & $(2.026 .116 .900)$ \\
\hline Depart. Finance dan & $(126.839 .040)$ \\
\hline Accounting & \\
\hline Depart. Direksi & $(64.408 .116)$ \\
\hline Depart. Manajer & $(7.788 .600)$ \\
\hline Total Beban Usaha & $(2.225 .152 .656)$ \\
\hline Laba Bersih Usaha & 2.639 .158 .905 \\
\hline \multicolumn{2}{|l|}{$\begin{array}{l}\text { Pendapatan dan Beban Lain- } \\
\text { lain: }\end{array}$} \\
\hline 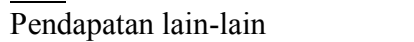 & 69.594 .096 \\
\hline Beban lain-lain & $(49.839 .120)$ \\
\hline Laba Bersih & 2.658 .913 .881 \\
\hline Rasio Laba Bersih dari & $16,74 \%$ \\
\hline Penjualan Bersih & $10, / 4 \%$ \\
\hline
\end{tabular}

Sumber: Data Diolah

Tabel 6

PT. Setia Makmur, Surabaya

Perhitungan Beban Pokok Penjualan

Untuk Tahun yang Berakhir pada

31 Desember 2016

(Penilaian Persediaan Metode Average)

\begin{tabular}{|l|r|}
\hline Persediaan Awal & 11.141 .789 .400 \\
\hline Pembelian & 11.891 .911 .212 \\
\hline Barang tersedia untuk & 23.033 .700 .612 \\
\hline Persediaan Akhir & $(12.012 .346 .293)$ \\
\hline Beban Pokok Penjualan & 11.021 .354 .319 \\
\hline
\end{tabular}

Sumber: Data Diolah
Tabel 7

PT. Setia Makmur, Surabaya

Neraca

Per 31 Desember 2016

(Penilaian Persediaan Metode Average)

\begin{tabular}{|r|r|}
\hline AKTIVA & \\
Aktiva Lancar: & \\
Kas dan setara kas & 843.122 .765 \\
Piutang Usaha & 2.667 .235 .650 \\
Putang lain-lain & 4.142 .955 .084 \\
Persediaan & 12.012 .346 .293 \\
Uang Muka Pembelian & 50.245 .865 \\
Biaya dibayar dimuka & 40.415 .498 \\
\hline Jumlah aktiva lancer & 19.756 .321 .155 \\
\cline { 2 - 2 } Aktiva Tetap : & \\
Nilai Perolehan & \\
Akumulasi Penyusutan & 2.980 .771 .258 \\
Jumlah aktiva tetap & $(1.455 .688 .839)$ \\
\cline { 2 - 2 } Total aktiva & 1.525 .082 .419 \\
\cline { 2 - 2 } KEWAJIBAN & \\
\cline { 2 - 2 } Kewajiban Jangka Pendek : & 21.281 .403 .574 \\
\cline { 2 - 2 } Hutang Giro & \\
Hutang Usaha & \\
Uang Muka Penjualan & \\
Hutang lain-lain & \\
Jumlah kewajiban jangka pendek & 5.922 .117 .967 \\
& 27.902 .393 \\
\cline { 2 - 2 } EKUITAS & 647.966 .533 \\
\cline { 2 - 2 } Modal & 6.750 .553 .820 \\
\hline Laba ditahan & \\
Laba tahun berjalan & 10.439 .419 .764 \\
Jumlah ekuitas & 1.432 .516 .109 \\
Total kewajiban dan ekuitas & 2.658 .913 .881 \\
\cline { 2 - 2 } Sumber: Data Diolah & \\
\cline { 2 - 2 } & 14.530 .849 .754 \\
\hline
\end{tabular}

Sumber: Data Diolah

Dengan menggunakan Metode Penilaian Persediaan LIFO (MTKP) besarnya nilai Beban Pokok Penjualan yang didapat berbeda dengan jika menggunakan Metode Penilaian Persediaan Average (Rata-rata). Jika perusahaan menggunakan Metode Penilaian Persediaan LIFO (MTKP), nilai Beban Pokok Penjualan sebesar Rp. 11.801.701.826,- (Tabel 2). Sedangkan jika menggunakan Metode Average (Rata-rata) Beban Pokok Penjualan sebesar Rp. 11.021.354.319,- (Tabel 6). Jadi ada perbedaan pembebanan Beban Pokok Penjualan sebesar Rp. 780.347.507,- antara penggunaan Metode Penilaian Persediaan LIFO (MTKP) dengan Metode Penilaian Persediaan Average (Rata-rata). 
Pembebanan nilai Beban Pokok Penjualan yang berbeda akan berdampak pula pada perhitungan Laba Bersih yang diperoleh. Dengan menggunakan Metode Penilaian Persediaan LIFO (MTKP), Laba Bersih yang diperoleh sebesar Rp. 1.878.566.374,dengan rasio Laba Bersih dari Penjualan Bersih sebesar 11,83\% (Tabel 1). Sedangkan jika menggunakan Metode Average (Rata-rata) Laba Bersih yang diperoleh menjadi sebesar Rp. 2.658.913.881,- dengan rasio Laba Bersih dari Penjualan Bersih sebesar 16,74\% (Tabel 5). Jadi ada perbedaan nilai Laba Bersih yang diperoleh sebesar Rp. 780.347.507,- antara penggunaan Metode penilaian persediaan LIFO (MTKP) dan Average (Ratarata).

Jadi dalam kondisi harga barang yang tidak stabil, penggunaan Metode Penilaian Persediaan Average akan lebih tepat dibandingkan dengan metode penilaian persediaan lainnya. Dalam kasus PT. Setia Makmur, Surabaya penggunaan Metode Penilaian Persediaan LIFO (MTKP) sangat tidak tepat dengan 2 alasan: (i) Metode Penilaian Persediaan LIFO (MTKP) tidak diperkenankan digunakan sesuai dengan ketentuan dari Standar Akuntansi Keuangan. (ii) Penggunaan Metode Penilaian persediaan LIFO (MTKP) pada kondisi harga yang cenderung naik terus akan menyebabkan nilai Beban Pokok Penjualan menjadi lebih tinggi dari pada yang seharusnya dan Laba Bersih yang diperoleh menjadi lebih rendah dari pada yang seharusnya.

Penggunaan metode pencatatan persediaan dengan menggunakan Metode Fisik (Phycical Method) juga cenderung tidak tepat, karena membuat pengendalian internal terhadap Persediaan Barang menjadi lemah.
Seharusnya PT. Setia Makmur, Surabaya menggunakan Metode Pencatatan Persediaan Perpetual.

\section{KESIMPULAN}

1. Perusahaan harus berhati-hati dalam memilih metode penilaian persediaan yang akan digunakan, karena kesalahan penentuan metode penilaian persediaan yang digunakan akan berakibat pada penyajian Beban Pokok Penjualan yang terlalu tinggi (overstated) atau terlalu rendah (understated) yang berakibat pula pada penyajian Laba Bersih yang terlalu tinggi (overstated) atau terlalu rendah (understated).

2. Pemilihan metode penilaian persediaan juga berpengaruh pada penyajian nilai Persediaan Barang, yang dapat disajikan terlalu tinggi (overstated) atau terlalu rendah (understated).

3. Dalam kondisi harga barang yang cenderung naik, penggunaan Metode LIFO (MTKP) oleh PT. Setia Makmur, Surabaya untuk menilai persediaan Barang Dagangannya tidak tepat, karena akan cenderung menghasilkan penyajian Beban Pokok Penjualan yang terlalu tinggi (overstated) dan Persediaan Barang Dagangan dan Laba Bersih yang terlalu rendah (understated).

\section{SARAN}

1. PT. Setia Makmur, Surabaya sebaiknya menggunakan Metode Penilaian Persediaan Average dibandingkan dengan Metode LIFO yang tidak diperbolehkan sesuai ketentuan dari Standar Akuntansi Keuangan, di samping juga akan dapat menyajikan nilai Persediaan Barang Dagangan, Beban Pokok 
Penjualan dan Laba Bersih yang lebih realisitis dan moderat.

2. PT. Setia Makmur, Surabaya sebaiknya menggunakan Metode Perpetual dari pada Metode Fisik untuk pencatatan persediaan, karena dari sudut pengendalian internal penggunaan Metode Perpetual akan menciptakan internal kontrol yang lebih baik.

\section{DAFTAR KEPUSTAKAAN}

Baridwan, Zaki, 2002, Intermediate Accounting, Cetakan Pertama, BPFE, Yogyakarta.

Carter, William K., 2009, Akuntansi Biaya, Buku Satu, Edisi Keempat Belas, Salemba Empat, Jakarta.

Halim, Abdul, 2002, Dasar-dasar Akuntansi Biaya, Buku Satu, Edisi Keempat, BPFE, Yogyakarta.

Harahap, Sofyan Syafri, 2005, Teori Akuntansi, Edisi Kedua, Cetakan Kesatu, PT. Raja Grafindo, Jakarta.

Horngren, Harrison, Robinson dan Secokusumo, 2004, Akuntansi di Indonesia, Edisi ketiga, Salemba Empat, Jakarta.

Ikatan Akuntansi Indonesia, 2012, Standar Akuntansi Keuangan, Salemba Empat, Jakarta.
Jumingan, 2014, Analisis Laporan Keungan, Cetakan Kelima, PT. Bumi Aksara, Yogyakarta.

Jusup, Al Haryono, 2005, Dasar-dasar Akuntansi, Jilid I, Edisi Keenam, BP STIE YKPN, Yogyakarta.

Kieso, Donald E. dan Jerry J. Weygandt, 2000, Akuntansi Intermediate, Jilid 1, Alih Bahasa Herman Wibowo, Cetakan Pertama, Edisi Ketujuh, Binarupa Aksara, Jakarta.

Munawir, 2012, Analisa Laporan Keuangan, Edisi Keempat, Liberty, Yogyakarta.

Samryn, L.M, 2015, Pengantar Akuntansi, Rajawali Pers, Jakarta.

Smith, Jay M. dan K. Fred Skousen, 2001, Akuntansi Intermediate, Edisi Kesembilan, Erlangga, Jakarta.

Supriyono, R.A., 2010, Akuntansi Biaya, Buku Satu, Edisi Dua, BPFE, Yogyakarta. 